\title{
Analysis of Factors on The Issuance of Sharia Bonds (Sukuk) and Sharia Shares on Company Performance in Jakarta Islamic Index 70
}

Bella Jastacia ${ }^{*}$, Ummu Salma Al Azizah ${ }^{2}$, Rito ${ }^{3}$

${ }^{1}$ Department of Economic Education, Universitas Muhammadiyah Prof. Dr. Hamka, Indonesia

2 Department of Economic Education, Universitas Muhammadiyah Prof. Dr. Hamka, Indonesia

${ }^{3}$ Department of Economic Education, Universitas Muhammadiyah Prof. Dr. Hamka, Indonesia

\begin{tabular}{l} 
ARTICLE INFO \\
\hline Article history: \\
Received Juny 14, 2021 \\
Revised September 14, 2021 \\
Accepted September 27, 2021 \\
Available online October 1, 2021 \\
Keywords: \\
Sukuk, Sharia stocks, RoA, Company \\
performance, JII 70 \\
Paper type: Research paper \\
Please cite this article [Turabian of \\
style 8th edition]: Jastacia, Bella, Al \\
Azizah, Ummu, AND Rito, Rito. " \\
Analysis Of Factors On The Issuance Of \\
Sharia Bonds (Sukuk) And Sharia \\
Shares On Company Performance In \\
Jakarta Islamic \\
70" IQTISHODUNA: Jurnal Ekonomi \\
Islam [Online], Volume 10 Number 2 (1 \\
October 2021)
\end{tabular}

*Corresponding author

e-mail: jastaciabella01@gmail.com

\section{ABSTRACT}

This study aims to analyze the effect of the issuance of Islamic bonds (sukuk) and the issuance of Islamic stocks on company performance in the Jakarta Islamic Index 70. The issuance of Islamic bonds and Islamic stocks is an alternative for companies to obtain a capital structure in carrying out company operations and is expected to improve the company's performance. In terms of financial performance through Return On Assets (ROA), company stakeholders optimize Islamic capital market products to increase Islamic financial inclusion. Besides, it attracts investors to invest. This study uses a quantitative descriptive method, secondary data from companies listed in the Jakarta Islamic Index 70 years 2018-2020 using a purposive sampling method with Tobin's analysis and company age into 15 samples. Testing the hypothesis model using the classic assumption test and multiple regression tests to test the market reaction to the issuance of Sukuk and Islamic shares on the issuance variable using the issuance value, the number of shares outstanding, company leverage, company size, total debt, and company managerial ownership. The research resultsstated thatReturn on Assets (ROA) was affected bythe issuance value variable and the company's leverage in 0.00192 and 0.0373 . The variables of the number of outstanding shares, total debt, firm size, and managerial ownership do not affect the value of ROA. However, all variables have a significant effect on the ROA value. The result shows that the issuance of Islamic bonds and Islamic stocks affects the company's performance.. IQTISHODUNA with CC BY license. Copyright $\odot$ 2021, the author(s)

Abstrak: Kemunculan Penelitian ini bertujuan untuk menganalisis pengaruh penerbitan obligasi syariah (sukuk) dan penerbitan saham syariah terhadap kinerja perusahaan di Jakarta Islamic Index 70. 
Penerbitan obligasi syariah dan saham syariah merupakan salah satu alternatif bagi perusahaan untuk memperoleh struktur modal. dalam menjalankan operasional perusahaan dan diharapkan dapat meningkatkan kinerja perusahaan. Dari sisi kinerja keuangan melalui Return On Assets (ROA), pemangku kepentingan perusahaan mengoptimalkan produk pasar modal syariah untuk meningkatkan inklusi keuangan syariah. Selain itu, menarik investor untuk berinvestasi. Penelitian ini menggunakan metode deskriptif kuantitatif, data sekunder dari perusahaan yang terdaftar di Jakarta Islamic Index 70 tahun 2018-2020 menggunakan metode purposive sampling dengan analisis Tobin dan umur perusahaan menjadi 15 sampel. Pengujian model hipotesis menggunakan uji asumsi klasik dan uji regresi berganda untuk menguji reaksi pasar terhadap penerbitan Sukuk dan saham syariah pada variabel penerbitan menggunakan nilai emisi, jumlah saham beredar, leverage perusahaan, ukuran perusahaan, total hutang, dan kepemilikan manajerial perusahaan. Hasil penelitian menyatakan bahwa Return on Assets (ROA) dipengaruhi oleh variabel nilai emisi dan leverage perusahaan sebesar 0,00192 dan 0,0373. Variabel jumlah saham beredar, total hutang, ukuran perusahaan, dan kepemilikan manajerial tidak berpengaruh terhadap nilai ROA. Namun, semua variabel berpengaruh signifikan terhadap nilai ROA. Hasil penelitian menunjukkan bahwa penerbitan obligasi syariah dan saham syariah berpengaruh terhadap kinerja perusahaan.

Kata kunci: Sukuk, Saham Syariah, RoA, Kinerja Perusahaan, JII 70

\section{INTRODUCTION}

One of the fastest-growing and dynamic economic domains that play a role in supporting increased economic growth in Indonesia is the capital market ${ }^{1}$. Based on Law No. 8 of 1995, the capital market is an essential activity in the negotiation process as well as the effects of trade ${ }^{2}$. Capital market instruments such as stocks, bonds, mutual funds, and other financial derivatives are now developing ${ }^{3}$. These things create healthy corporate circumstances.

The Islamic capital market is an alternative for investors because it has sharia principles in every

\footnotetext{
${ }^{1}$ Khairunnisa Musari, "Esham, the Origin of Sukuk for Facing the Crisis: Historical Experience," IQTISHODUNA: Jurnal Ekonomi Islam 10, no. 1 (2021): 45-48.

2 Aminatuz Zahroh, "Instrumen Pasar Modal," IQTISHODUNA: Jurnal Ekonomi Islam 4, no. 1 (2015): 51-65.

3 Elliv Hidayatul Lailiyah and Rahmat Setiawan, "Stock Selectivity Skill, Market Timing Ability, Risiko, Size, and Comparison of Performance Islamic Share Mutual Funds," IQTISHODUNA: Jurnal Ekonomi Islam 9, no. 2 (2020): 137-150.
}

economic transaction activity ${ }^{4}$. In QS. At-Taubah verse 34, which means "And those who keep gold and silver and do not spend it in the way of Allah, then give them good news (that they will get) a painful punishment."This verse is the essential background and reasons for integrating sharia principles into capital market operations. Sharia stocks are evidence of a company's claims, while Islamic bonds are investment products issued by companies, simultaneously using the reciprocityprinciple in providing benefits to investors. The company issues Islamic shares and Islamic bonds to fund the company's operations in order to achieve the company's goals. Sharia bond provisions arecontained in the National Sharia Board Number 32 / DSN-MUI / IX / 2002, and sharia shares in the National Sharia Board Number 80 explain the mechanisms

\footnotetext{
${ }^{4}$ Abd Wadud Nafis, "Akad-Akad Di Dalam Pasar Modal Syariah," Iqtishoduna: Jurnal Ekonomi Islam 4, no. 1 (2015): 66-86.
} 
for trading securities and sharia compliance in details.

The issuance of Islamic bonds and Islamic stocks in Indonesia increased in 2016. This statement was proven by the capitalization value of JII of Rp. 2,041.07 billion at the same time, the market capitalization value of ISSI has increased from Rp. 2,600.85 billion to Rp. 3,170.06 billion in 2016. Besides, this development was followed by an increase in the value of sukuk, which took third place as Top Countries in Outstanding sukuk in 2018, valued at US \$ 51 billion. In 2018 the value of corporate sukuk increased from $35.32 \%$ to Rp. 21.3 trillion compared to the previous period, and there was an increase in the number of outstanding sukuk by 99 series, increasing $25.32 \%$ compared to last year.

This increase is an opportunity in the Islamic financial inclusion instrument in the capital market for expansion in grounding the principles of sharia in Indonesia. In addition, Islamic stocks and Islamic bonds (sukuk) can improve the company's performance, represented by the value of the company's Return on assets. Even though it has increased, the shortage of public understanding of the Islamic capital market due to the lack of socialization carriedout by related institutions indicates a lack of investor interest in investing.Investors' investment decisions will be tested in this study by linking the issuance of Islamic bonds (sukuk) and Islamic stocks.

On Hadi and Savitri's research show that the issuance of Islamic bonds does not significantly affectROA and stock returns.In contrast, Iskandar and Ridwan and Dwiana stated that the issuance of sukuk affects stock returns. ${ }^{5}$ supported this statement, which stated that it would affect stock returns and changing times and periods. Researches on the issuance of Islamic stocks by Zaman and Yunan show that the issuance of Islamic stocks has a significant effect. However, in Fadli's study, Return On Assets does not affect company capital.

Based on the background showed, researchers are interested in researching factors on the issuance of Islamic bonds and Islamic stocks on company performance in the Jakarta Islamic Index 70. Islamic capital market portfolio information, policymakers, and the academic community to increase literacy in determining the best investment in all situations from the information obtained by investors.

\footnotetext{
${ }^{5}$ Savitri E, "Pengaruh Penerbitan Obligasi Syariah (Sukuk) Terhadap Reaksi Pasar Modal Indonesia," Jurnal Aplikasi Manajemen (2015).
} 


\section{Return on Asset}

The calculation of return results from the difference between the current price and the previous price, which is the value of the company's profitability ${ }^{6}$. Return on assets is a profitability ratio that measures the company's ability to generate profits or profits from users of owned assets. In this case, all assets obtained from both internal and external companies. The company has converted it in the form of company assets. ROA is used to evaluate management whether it is being carried out according to the company's objectives.

\section{METHODS}

This research is a library study since the collected data are library data which are relevant to the research problems. This study is a quantitative study because the data are presented in the form of words not numbers7. Research whose results are not statistics or elaboration of calculations. ${ }^{8}$

This study used a quantitative descriptive method

6 A. A. Y Fadli, "Pengaruh Profitabilitas Terhadap Modal Kerja Pada Perusahaan Makanan Dan Minuman Yang Terdaftar Di Bursa Efek Indonesia," Aplikasi Manajemen, Ekonomi, Dan Bisnis. (2017).

${ }^{7}$ Anselm STRAUSS and Julia Corbin, DasarDasar Penelitian Kualitatif: Tata Langkah Dan Teknik-Teknik Teoritisasi Data (Yogyakarta: Pustaka Belajar, 2007).

8 STRAUSS and Corbin, Dasar-Dasar Penelitian Kualitatif: Tata Langkah Dan Teknik-Teknik Teoritisasi Data (Yogyakarta: Pustaka Belajar, 2007). with statistical tools, hypothesis testing, and multiple regression to test the market reaction to the issuance of sukuk and Islamic stocks on the variables of issuance value, number of shares outstanding, company leverage, total debt, company size, and company managerial ownership.

This study used secondary data from companies listed on the Jakarta Islamic Index 70 years 20182020. The research sample used purposive sampling, which has these criteria: 1) companies pass the Tobin test in measuring firm value 2) companies with age above 25 years. 3) sukuk and sharia share issuing companies listed on IDX. In this research, 15 companies are ready to be analyzed as the results.

This study used multiple linear regression analysis with the equation:

$$
\hat{y}=b_{o}+b_{2} x_{1}+b_{2} x_{2}+b_{2} x_{2}+b_{4} x_{4}+b_{2} x_{2}+b_{4} x_{6}
$$

The operational definition of company.

\section{Dependent variable}

Return on Asset is used to measure the company's performance when issuing Islamic bonds and Islamic stocks. It is a reflection of investor behaviour on the issuance announcement. To measure the Return on Assets with the formula: ROA

\section{NET INCOME}

\section{TOT AL ASSETS}




\section{Independent variable}

The independent variable in the research on sukuk and Islamic stock publications was measured from the first, the number of shares being measured. The market capitalization available on the exchange was directly proportional to the number of shares transferred, following the company's needs ${ }^{9}$. However, the risk is higher if the dead shares do not attract investors to develop. Then, the number of shares will have a negative effect on Return on Assets.

The second variable was the nominal value of the sukuk and the entire company. The types and numbers of sukuk issued by companies vary ${ }^{10}$. A large issuance will cause a significant risk of default, so the value of the sukuk publication has a negative effect on Return on Assets.

The third variable is the total debt capital used to measure investment in the company (Martina, 2019). However, it must be in a proportional amount. Then the total equity debt has a negative effect on Return on Assets. The fourth variable is the company's total debt that the company must

\footnotetext{
${ }^{9}$ C. Y. Ida, I. D. A., \& DWINTA, “Pengaruh Locus Of Control, Financial Knowledge, Income Terhadap Financial Management Behavior," Jurnal Bisnis dan Akuntansi 12, no. 3 (2010): 131-144.

10 M. C. Syarifudin, A., Afifudin, A., \&Mawardi, "PENGARUH PENERBITAN SUKUK TERHADAP REAKSI PASAR MODAL SYARIAH (StudiEmpiris Di BEI Tahun 2018)," Jurnal Ilmiah Riset Akuntansi 8 , no. 10 (2019).
}

pay for the company's operational interests ${ }^{11}$. The greater issuance of Islamic bonds (sukuk) and Islamic stocks help pay the company's total debt. Then the company's total debt has a positive effect on Return on Assets.

The fifth variable, managerial ownership, is the proportion of shareholders from the management, which will affect the company's performance in supervising company activities ${ }^{12}$. This will pose a risk to the top management of the company that owns the company. If a collapse occurs, it will be easy to be acquired by investors. Thus, managerial ownership has a negative effect on Return on Assets.

The sixth variable, company size sourced from the company's financial statements. The greater company's assets, the greater return received by the company ${ }^{13}$. However, company size has a positive effect on Return on Assets.

\footnotetext{
11 A. R. Pambudi, "Pengaruh Profitabilitas, Likuiditas, Ukuran Perusahaan, Pertumbuhan, Umur Obligasi Dan Jaminan Terhadap Peringkat Obligasi Pada Perusahaan Industri Transportasi," in Doctoral Dissertation (SURABAYA: STIE PERBANAS SURABAYA, 2017).

12 Pujiati Diyah \& Erman Widanar, "Pengaruh Struktur Kepemilikan Terhadap Nilai Perusahaan: Keputusan Keuangan Sebagai Variabel Intervening," urnal Ekonomi dan Bisnis dan Akuntansi Ventura 12, no. 1 (2009): 71 - 86.

13 A. Hardianti N. I. \& Widarjono, "Dampak Penerbitan Sukuk Dan Obligasi Konvensional Terhadap Return Saham Perusahaan Di Indonesia," Jurnal Ekonomi dan Keuangan Islam 3, no. 1 (2017): 43-51.
} 


\section{RESULTS AND DISCUSSION}

This research used the classic assumption test. It consists of normality test, heteroscedasticity test, multicollinearity test, and autocorrelation test, which previously explained the average value, highest value, lowest value, and standard deviation of each data from the variables in table 1 as follows:

\section{Table 1 Descriptive statistics}

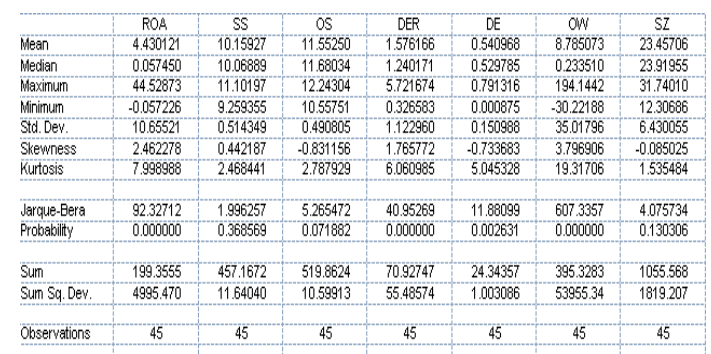

Table 1 explains the results of descriptive statistics.The highest number of shares outstanding (SS) of the company is 11.10197 , with the lowest value of 9.259355. for the variable value of sukuk issuance (OS) the highest is 12.24304, and the lowest value is 10.55751 . The highest corporate leverage ratio (DER) variable is 5.721674 , and the lowest value is 0.326583 . The highest total debt (DE) variable is 0.791316 , and the lowest value is 0.000875 . The highest managerial ownership variable $(\mathrm{OW})$ is 194.1442 , with the lowest value -30.222188 . The highest company size variable (SZ) is 31.74010 with the lowest value being 12.30686 .

a normal probability plot graph is shown in Figure 1 below

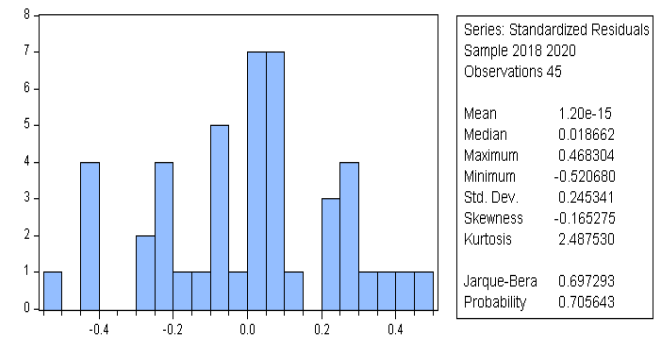

Figure 1 normal probability plot graph

a normal probability plot graph shows a normal graph pattern. These graphs show that the probability value is 0.705643 , which is greater than alpha (0.05). So the conclusion is that the model is feasible to use because it meets the assumption of normality.

Table 2 Heteroscedasticity Test Results

\begin{tabular}{|c|c|c|c|c|}
\hline & & & & \\
\hline Variable & Coefficient & Std. Error & t-Statistic & Prob. \\
\hline$c$ & 90.06205 & 75.07764 & 1.199586 & 0.2377 \\
\hline SS & -5.455701 & 5.726574 & -0.952699 & 0.3468 \\
\hline OS & -1.682927 & 5.273959 & -0.319101 & 0.7514 \\
\hline DER & -1849326 & 2.287667 & -0.808390 & 0.4239 \\
\hline$D E$ & -8.063571 & 10.65985 & -0.756443 & 0.4540 \\
\hline OW & 0.007150 & 0.041090 & 0.174015 & 0.8628 \\
\hline$S Z$ & -0.151332 & 0.254834 & -0.593847 & 0.5561 \\
\hline
\end{tabular}

In Table 2, it can be seen that the Prob. all independent variables $>0.05$. Thus it can be concluded that the overall variables in the regression model are free from heteroscedasticity problems 
Table 3 Multicollinearity Test Results

\begin{tabular}{|c|c|c|c|c|c|c|}
\hline & SS & OS & DER & DE & ON & $S 2$ \\
\hline$S S$ & 1.000000 & 0.226617 & .0 .502785 & 0.211258 & .0 .02227 & .0 .07615 \\
\hline $0 S$ & 0.226617 & 1.000000 & .0 .057412 & 0.081562 & 0.044630 & 0.127906 \\
\hline DER & .0502785 & 0.057412 & 1.000000 & 0.296181 & 0.010249 & 0.051343 \\
\hline DE & 0.211258 & 0.081562 & 0.296181 & 1.000000 & 0.068312 & .0 .289120 \\
\hline OW & 0.022227 & 0.044630 & 0.010249 & 0.068312 & 1.000000 & 0.046018 \\
\hline SI & .0 .087615 & 0.127906 & 0.051343 & .0 .289120 & 0.048018 & 1.000000 \\
\hline
\end{tabular}

According to these results, each variable has a coefficient value $<0.9$ | which means that the model avoids multicollinearity symptoms.

Table 4 Autocorrelation Test Results

\begin{tabular}{|c|c|c|c|}
\hline R-squared & 0.279965 & Mean dependent var & $0.31928=$ \\
\hline Adjusted R-squared & 0.166275 & S.D. dependent var & 0.278734 \\
\hline S.E. of regression & 0.254508 & Akaike into criterion & 0.24306 \\
\hline Suln squared resid & 2.461424 & Schwarzcrterion & $0.52410^{\circ}$ \\
\hline Log likelihood & 1.531018 & Hannan-Quinn criter. & 0.3478 \\
\hline F-statistic & 2.462536 & Durbin-Watson stat & $1.86760^{2}$ \\
\hline Prob(F-statistic) & 0.041333 & & \\
\hline
\end{tabular}

The Durbin-Watson value is 1.867602 with the number of independent variables and samples is six or $\mathrm{k}=6$; The number of samples is 45 or $n=45$, the value of the Durbin-Watson table is obtained $\mathrm{dL}=1.238$ and $\mathrm{dU}=1.835$. Referring to the provisions of $\mathrm{dU}<\mathrm{d}<4-\mathrm{dU}$ or $1,835<1,867<2.165$, the data is free from autocorrelation assumption symptoms.

Table 5 Results of the regression test

\begin{tabular}{|c|c|c|c|c|}
\hline Variable & Coefficient & Std. Error & t-Statistic & Prob. \\
\hline C & 4.197214 & 1.173813 & 3.575709 & 0.0010 \\
\hline SS & -0.165877 & 0.090147 & -1.840065 & 0.0736 \\
\hline Os & -0.202642 & 0.082875 & -2.445139 & 0.0192 \\
\hline DER & -0.087922 & 0.040735 & -2.158374 & 0.0373 \\
\hline $\mathrm{DE}$ & 0.173175 & 0.288187 & 0.600911 & 0.5515 \\
\hline$O W$ & $-3.38 \mathrm{E}-06$ & 0.001102 & -0.003073 & 0.9976 \\
\hline $\mathrm{SZ}$ & 0.008237 & 0.006488 & 1.269578 & 0.2120 \\
\hline
\end{tabular}
results in Table 4.5 above, the regression equation can be formulated as follows:
$\mathrm{ROA}=4.197214-0.165877$ SS 0.202642 OS - 0.087922 DER + $0.173175 \mathrm{DE}-3.38 \times 10-6 \mathrm{OW}+$ $0.008237 \mathrm{SZ}+\mathrm{e}$

The analysis of the regression equation above:

Based on the results of the regression equation above, a constant value of 4.197214 is obtained. It can be concluded that if all independent variables are considered constant, the resulting value of the ROA variable is 4.197214 .

Based on the regression equation above, all independent variables have negative regression coefficients except for DE and SZ variables. So, the independent variables SS, OS, DER, and OW negatively affect the ROA variable, while DE and SZ positively correlate to the ROA variable.

Simultaneous Significance Test (Test Statistic F)

The $\mathrm{F}$ test in this study is a test carried out to determine the relationship between the independent and dependent variables, whether the SS, OS, DER, $\mathrm{DE}, \mathrm{OW}$, and SZ variables influence the dependent variable ROA simultaneously. $\mathrm{F}$ in this study can be seen in Table 6 below:

Table 6 F Test Results

\begin{tabular}{|c|c|c|c|}
\hline R-squared & 0.279965 & Mean dependent var & 0.319289 \\
\hline Adjusted R-squared & 0.166275 & S.D. dependent var & 0.278734 \\
\hline S.E. of regression & 0.254508 & Akaike into criterion & 0.243066 \\
\hline Sum squaredresid & 2.461424 & Schwarzcriterion & 0.524102 \\
\hline Log likelihood & 1.531018 & Hannan-Quinn criter. & 0.347833 \\
\hline F-statistic & 2.462536 & Durbin-Watson stat & 1.867602 \\
\hline Prob(F-statistic) & 0.041333 & & \\
\hline
\end{tabular}


From F-test's result in Table 4.6 , it can be seen that the probability is $0.041333<0.05$, so $\mathrm{H} 0$ is rejected. This result shows a significant influence between SS, OS, DER, DE, OW, and SZ variables simultaneously on the ROA variable.

Significant Test for Individual Parameters (t Statistical Test)

Following are the results of the significant test for individual parameters:

Table 7 Results (t test)

\begin{tabular}{|c|c|c|c|c|}
\hline & & & & \\
\hline Variable & Coefficient & Std. Error: & t-Statistic & Prob. \\
\hline $\mathrm{C}$ & 4.197214 & 1.173813 & 3575709 & 0.0010 \\
\hline SS & -0.165877 & 0.090147 & -1.840065 & 0.0736 \\
\hline OS & -0.202642 & 0.082875 & -2.445139 & 0.0192 \\
\hline DER & -0.087922 & 0.040735 & -2.158374 & 0.0373 \\
\hline $\mathrm{DE}$ & 0.173175 & 0.288187 & 0.600911 & 0.5515 \\
\hline ON & $-3.38 E-06$ & 0.001102 & -0.003073 & 0.9976 \\
\hline SZ & 0.008237 & 0.006488 & 1.269578 & 0.2120 \\
\hline
\end{tabular}

Table 7 the t-test results show that the probability of OS and DER variables $<0.05$, then $\mathrm{H} 0$ is rejected. This result means that the SS, OS, and DER variables significantly influence the ROA variable. While the variables SS, DE, OW, and SZ> 0.05 , then $\mathrm{HO}$ is accepted. It means that SS, DE, OW, and SZ do not significantly affect the ROA variable individually.

\section{DISCUSSION}

The analysis of the two models shows that the issuance of Islamic stocks and Islamic bonds (sukuk) on company performance is influenced by the OS and DER of a company registered in JII 70 and identified by Tobin's value and company age.

The effect of the issuance of Sharia bonds and Shariastocks on company's performance.

Simultaneously, the variables SS, OS, DER, DE, OW, and SZ affect ROA in companies listed in JII 70.The relationship between the issuance of Islamic bonds and Islamic stocks is due to alleged strategic information, including the source and use of assets that have fixed costs. In order to get an optimal profit or return, Return on Assets directly improves the company's performance. This lines with Hadi, which is marked by good financial performance. With this good financial performance, it will increase the price of Islamic stocks and the selling power of Islamic bonds (sukuk) in the Islamic capital market. However, partially the SS and DER variables affect the company's performance on the issuance of Islamic stocks and Islamic bonds (sukuk). This is related to Herlambang's (2015) research that the rating value and the number of Islamic bonds (sukuk) offered and the Debt to Equity Ratio affect attracting investors to invest in the company. Thus, the OS and DER variables have an individual effect in improving the company's performance, particularly Return On Asset, when the company issues sukuk and Islamic stocks. 


\section{Conclusion}

Based on the results of data processing obtained by multiple regression analysis using data analysis Eviews 10 shows that the variables SS, OS, DER, DE, OW, and SZ and ROA have an average value of 10.16 each; $11.55 ; 1.580 .54 ; 8.78$; $23.46 ; 4.43$; and for the minimum value respectively $9.26 ; 10.56 ; 0.33$; $0.000875 ;-30.02 ; 6.43 ;-0.06$ and has a maximum value of $11.10 ; 12,24 ; 5.72$; $0.79 ; 194.14 ; 31.74 ; 44.53$;

According to the classical assumption test results, it is found that the residual value is normally distributed, there are no symptoms of heteroscedasticity, autocorrelation, and multicollinearity. So that the multiple regression model for processed panel data is Best Linear Un] (BLUE). The partial hypothesis test shows that the value of Islamic bonds or OS is 0.0192; The DER of 0.0373 has a significant effect on the company's performance as represented by ROA.

The simultaneous hypothesis testing shows that all independent variables significantly influence the dependent variable with a significance value of 0.041333 . Meanwhile, the Adjusted R2 value, a value of 0.166275 , was obtained. It means that all existing variables represent and can influence the dependent variable of $16.6275 \%$, which was carried out by this study. Suggestions

This study only used secondary data from financial reports listed on the Jakarta Islamic
Index 70 and supported data from the stock exchange and OJK. The results of this study, the total debt capital, and the value of the issuance of Islamic bonds affect. Simultaneously, all variables affect the ROA value. The use of Tobin here is only for sampling. It would be better if it added the Altman $Z$ score to measure the company indepth so that the samples used are more reliable. 


\section{REFERENCE}

Diyah, Pujiati., \& Widanar, Erman. (2009). Pengaruh struktur kepemilikan terhadap nilai perusahaan: Keputusan Keuangan Sebagai Variabel Intervening. Jurnal Ekonomi dan Bisnis dan Akuntansi Ventura, 12 (1), 71 - 86.

Dwiana, M. (2020). Pengaruh Penerbitan Obligasi Syariah Terhadap Return Saham (Studi Kasus Pada Perusahaan Yang Menerbitkan Obligasi Syariah dan Terdaftar Pada Bursa Efek Indonesia (BEI). Jurnal Bisnis, Manajemen, Dan Ekonomi. https:/ / doi.org/10.47747/jbme.v1i2.13

Fadli, A. A. Y. (2017). Pengaruh Profitabilitas terhadap Modal Kerja pada Perusahaan Makanan dan Minuman yang Terdaftar di Bursa Efek Indonesia. Aplikasi Manajemen, Ekonomi, Dan Bisnis.

Hadi, F. (2018). PENGARUH PENERBITAN SUKUK TERHADAP KINERJA KEUANGAN BANK SYARIAH MANDIRI TAHUN 2003-2014 SKRIPSI. Director.

Hardianti, N. I., \&Widarjono, A. (2017). Dampak penerbitan sukuk dan obligasi konvensional terhadap return saham perusahaan di Indonesia. Jurnal Ekonomi dan Keuangan Islam, 3(1), 43-51.

Ida, I. D. A., \& DWINTA, C. Y. (2010). Pengaruh Locus Of Control, financial knowledge, income terhadap financial management behavior. Jurnal Bisnis dan Akuntansi, 12(3), 131-144.

Iskandar, M., \& Ridwan, R. (2019). PENGARUH PENERBITAN SUKUK TERHADAP REAKSI PASAR (SURVEY TERHADAP PERUSAHAAN-PERUSAHAAN YANG MENERBITKAN OBLIGASI SYARIAH .... Jurnal Ilmiah Mahasiswa Ekonomi.

Lailiyah, Elliv Hidayatul, and Rahmat Setiawan. 2020. "Stock Selectivity Skill, Market Timing Ability, Risiko, Size, and Comparison of Performance Islamic Share Mutual Funds." IQTISHODUNA: Jurnal Ekonomi Islam 9 (2): 137-150.

Martina, P. S., \& Aisyah, I. S. (2019). PENGARUH KEBIJAKAN DIVIDEN, PROFITABILITAS, LIKUIDITAS, DAN LEVERAGE TERHADAP KEBIJAKAN PEMBELIAN KEMBALI SAHAM (Studi Pada Perusahaan Pertambangan yang Terdaftar di Bursa Efek Indonesia Periode 2012-2016) (Doctoral dissertation, Perpustakaan FEB-UNPAS BANDUNG).

Musari, Khairunnisa. 2021. "Esham, the Origin of Sukuk for Facing the Crisis: Historical Experience." IQTISHODUNA: Jurnal Ekonomi Islam 10 (1): 45-58.

Nafis, Abd Wadud. 2015. "Akad-Akad Di Dalam Pasar Modal Syariah." Iqtishoduna: Jurnal Ekonomi Islam 4 (1): 66-86.

Pambudi, A. R. (2017). Pengaruh Profitabilitas, Likuiditas, Ukuran Perusahaan, Pertumbuhan, Umur Obligasi dan Jaminan Terhadap Peringkat Obligasi pada Perusahaan Industri Transportasi (Doctoral dissertation, STIE PERBANAS SURABAYA).

Putri, Rianda Ajeng Ardiyanti \& Herlambang, L. (2015). Pengaruh Penerbitan Sukuk Ijarah terhadap ROA, ROE dan Earning Per Share Emiten di BEI Tahun 2009-2013. Jurnal JESTT.

Savitri, E. (2015). Pengaruh Penerbitan Obligasi Syariah (Sukuk) terhadap Reaksi Pasar Modal Indonesia. Jurnal Aplikasi Manajemen.

Syarifudin, A., Afifudin, A., \&Mawardi, M. C. (2019). PENGARUH PENERBITAN SUKUK TERHADAP REAKSI PASAR MODAL SYARIAH (StudiEmpiris di BEI tahun 2018). JurnalIlmiahRisetAkuntansi, 8(10).

Yuliawati, R. (2018). Analisis Pengaruh Penerbitan Obligasi Syariah (Sukuk) terhadap Reaksi Pasar. Journal of Chemical Information and Modeling.

Yunan, Z. Y., \& Rahmasari, M. (2015). Measurement Of Shariah Stock Performance Using Risk Adjusted Performance. Al-Iqtishad: Jurnal Ilmu Ekonomi Syariah, 7(1), 127-140. https://doi.org/10.15408/aiq.v7i1.1364

Zaman, F., \& Tinggi Ilmu Ekonomi Sebelas April, S. (2020). PENGARUH SAHAM SYARIAH SUKUK DAN REKSADANA SYARIAH TERHADAP PERTUMBUHAN EKONOMI NASIONAL TAHUN 2015 - 2019. In JURNAL ILMIAH EKONOMI DAN BISNIS TRIANGLE .

Zahroh, Aminatuz. 2015. "Instrumen Pasar Modal." IQTISHODUNA: Jurnal Ekonomi Islam 4 (1): 51-65. 